\title{
DISEASE FREE SURVIVAL OF STAGE I ENDOMETRIAL CANCER AFTER SURGERY WITH OR WITHOUT ADJUVANT TREATMENT
}

\author{
Woraluk Moradokkasem ${ }^{1}$, Nungrutai Saeaib ${ }^{1}$, Tippawan Liabsuetrakul ${ }^{2}$ \\ ${ }^{1}$ Department of Obstetrics and Gynecology, ${ }^{2}$ Epidemiology unit, Faculty of Medicine, Prince of Songkla University, \\ Hat Yai, Songkhla, Thailand
}

\section{ABSTRACT}

\begin{abstract}
This study aimed to define the disease free survival (DFS) and factors associated with recurrence in stage I endometrial cancer after surgery with and without adjuvant treatment. The demographic data, pathological results, adjuvant treatment (AT) and the outcome of patients with endometrial cancer stage I after surgery in Songklanagarind Hospital between January 2002 and July 2014 were collected. The DFS was analyzed by survival analysis and represented by Kaplan-Meier curves. The difference of DFS between AT and non-adjuvant treatment (NAT) groups was tested by the log-rank test. Distributions of risk factors by AT and recurrent status were analyzed using chi-square or Fisher exact tests for discrete factors, and unpaired tor Wilcoxon rank-sum tests for continuous factors. The 5-year DFS was; 91.6\%, from a total of 268 patients. DFS in the NAT group was significantly better than that in the AT group $(95.2$ versus $86.5 \%$, p-value $=0.01)$. Factors associated with recurrence in the NAT group were age, tumor grading, tumor size, and presence of lymphovascular involvement. Among the AT group, age and ratio of myometrial invasion were associated with recurrence. DFS in NAT was better than in AT and the potential factors associated with recurrence, after surgery with or without $A T$, were not the same.
\end{abstract}

Keywords: Survival; endometrial cancer; surgery

\section{ABSTRAK}

Penelitian ini bertujuan untuk menentukan disease free survival (DFS) dan faktor yang terkait dengan kekambuhan pada kanker endometrium stadium I setelah operasi dengan dan tanpa pengobatan tambahan. Data demografis, hasil patologis, adjuvant treatment (AT) dan hasil pasien dengan kanker endometrium stadium I setelah operasi di Rumah Sakit Songklanagarind antara Januari 2002 hingga Juli 2014 dikumpulkan. DFS dianalisis dengan analisis survival dan direpresentasikan menggunakan kurva Kaplan-Meier. Perbedaan DFS antara kelompok AT dan kelompok non-adjuvant treatment (NAT) diuji dengan uji log-rank. Distribusi faktor-faktor risiko dengan AT dan status berulang dianalisis menggunakan uji chi-square atau Fisher untuk faktor-faktor diskrit, dan uji t-sum Wilcoxon t tidak berpasangan untuk faktor kontinu. DFS 5 tahun adalah; 91,6\% dari total 268 pasien. DFS pada kelompok NAT secara signifikan lebih baik daripada pada kelompok AT (95,2 berbanding 86,5\%, p-value = 0,01). Faktor yang terkait dengan kekambuhan pada kelompok NAT adalah usia, kadar tumor, ukuran tumor, dan adanya keterlibatan limfovaskular. Di antara kelompok AT, usia dan rasio invasi miometrium dikaitkan dengan kekambuhan. DFS di NAT lebih baik daripada AT dan faktor-faktor potensial yang terkait dengan kekambuhan, setelah operasi dengan atau tanpa AT, tidak sama.

Kata kunci: Kelangsungan hidup, kanker endometrium; pembedahan

Correspondence: Nungrutai Saeaib, Department of Obstetrics and Gynecology, Faculty of Medicine, Prince of Songkla University, Hat Yai, Songkhla, 90110, Thailand. Phone: (66)74-451201-2, Fax: (66) 74-429617.

E-mail: snungrut@medicine.psu.ac.th

pISSN:2355-8393 • eISSN: 2599-056x • doi: http://dx.doi.org/10.20473/fmi.v55i1.12553

- Fol Med Indones. 2019;55:37-42• Received 9 Nov $2018 \bullet$ Accepted 21 Feb 2019

- Open access under CC-BY-NC-SA license • Available at https://e-journal.unair.ac.id/FMI/

\section{INTRODUCTION}

Endometrial cancer is the sixth most common disease in women and the 15 th most common cancer worldwide in 2018, the incidence was 24.9 per 100,000 women (Wolrd Cancer Research Fund \& American Institute for Cancer Research 2018). In Thailand, the incidence rate is 4.3 per 100,000 women (Imsamran et al 2015).
Approximately, 70-80\% of patients were presented as International Federation of Gynecology and Obstetrics (FIGO) stage I (Colombo et al 2016, Kim et al., 2016). The standard treatment has been changed from clinical to surgical staging (Haltia et al 2014). As a result, hysterectomy with bilateral salpingooophorectomy (BSO) is now practiced. The pelvic and paraaortic lymph nodes are both dissected based on risk factors of 
high metastasis, histological type tumor grading, tumor size, depth of myometrial invasion (MI), and the presence of extrauterine disease (Hacker et al 2015).

The majority of endometrial cancer was stage I and treatment with surgical staging that lead to a good prognosis. The 5-year overall survival (OS) rate was reported in the range of 76.4-95.3\% (Creutzberg et al 2000, Jeppesen et al 2016, Kim et al 2016, Koskas et al 2016, Lajer et al 2012) and the recurrence rate (RR) was 3.8-9.2\% (Creutzberg et al 2000, Jeppesen et al 2016, Keys et al 2004, Lajer et al 2012, Rahatli et al 2014). Because of this recurrence, adjuvant treatment (AT) was considered to be beneficial for prevention. To date, there are many worldwide guidelines for AT, such as the Post-Operative Radiation Therapy in Endometrial Carcinoma-1 (PORTEC-1) (Creutzberg et al 2000), Gynecologic Oncology Group study-99 (GOG-99) (Keys et al 2004) and National Comprehensive Cancer Network (NCCN) (NCCN 2018). Recurrence still occurs even in patients who received the adjuvant treatment. These patients are affected by many potential risk factors that consist of; age, histological type, tumor grading, presence of lymphovascular space invasion (LVSI), and MI (Colombo et al 2016, Creutzberg et al 2000, Keys et al 2004, NCCN 2018).

Our study aimed to define the disease free survival (DFS) of patients in stage I endometrial cancer after surgery between non-adjuvant treatments (NAT) and AT groups as well as to explore the distribution of potential risk factors by AT and recurrent status.

\section{MATERIALS AND METHODS}

\section{Study design and participants}

This retrospective descriptive study was approved by the Ethics Committee of the Faculty of Medicine, Prince of Songkla University (EC 59-169-12-4, June 9th, 2016). All patients with stage I endometrial cancer based on FIGO 2009, who underwent treatment in Songklanagarind Hospital from January 2002 to July 2014, were eligible. Patients, who had a history of other cancers or carcinosarcoma type, and a follow-up time of less than 2 years, were excluded. The standard treatment was hysterectomy with BSO and lymphadenectomy was based on risk factors of high metastasis; histological type tumor grading, tumor size, depth of MI, and the presence of extrauterine disease (Colombo et al 2016, Hacker et al 2015). The AT after surgery in Songklanagarind Hospital was performed in patients who had a high risk for recurrence of the disease, following the guidelines of PORTEC-1; age $=60$ years, grade 3 and ratio of MI more than $50 \%$ (Creutzberg et al., 2000), GOG-99; age 50-70 years and risk factors of grade 2-3, presence of LVSI and outer-thied MI (Keys et al., 2004) and NCCN; age $=60$ years, depth of MI, presence of LVSI (NCCN 2018).

\section{Data collection}

The hospital's number of patients with stage I endometrial cancer were recruited from the gynecologic tumor registry of 2002-2014. The data of these patients were reviewed from the Hospital Information System and recorded into a data record form. The demographic and histologic data included; age, parity, body mass index (BMI), medical co-morbidity; diabetes mellitus (DM), hypertension, and dyslipidemia, the time from diagnosis to surgery, operative procedure, histological type, tumor grading, tumor size, ratio of MI, presence of LVSI, cytology result, FIGO stage, adjuvant treatment, recurrent status and site. Patients were followed up with pelvic examinations, every 2-4 months for 2 years, every 3-6 months for 3 years. In addition, the patients had annual follow-up investigations that included; hematology, chemistry profile, and chest $\mathrm{x}$-ray. Chest/abdominal/pelvic computed tomography-scans were performed when clinically indicated. The DFS was defined as; the time from surgical staging to clinical, histologic, or radiographic evidence of disease recurrence, or the date of last follow-up, if the patients were alive without recurrence. The current status of all patients was searched from the follow-up data in the tumor clinic and civil registration, with the follow-up time ending on June 30th, 2016.

\section{Statistical analysis}

Two samples to test for a difference in the disease hazard were used to calculate the sample size. The minimal follow-up time was 2 years and the maximum time was 13 years. A $95 \%$ confident interval and the type II errors were 1.96 and 0.84 , respectively. The incidence rate of recurrence in the NAT group was 0.14 and in AT group it was 0.08 (Keys et al 2004). The sample size with a $5 \%$ adjustment for incomplete data in each group was 106 patients.

EpiData 3.1 and Rstudio 3.0.1(The R Foundation for Statistical Computing 2008, Austria) were used to collect and analyze the data. The DFS was analyzed by survival analysis, and presented by Kaplan-Meier curves. The difference of the DFS between the AT and NAT group was tested by the log-rank test. The distributions of potential risk factors by AT and recurrent status were analyzed using chi-square or Fisher's exact tests for discrete factors and unpaired $t$ or Wilcoxon rank-sum tests for continuous factors. A p- 
value of less than 0.05 was considered to be statistically significant.

\section{RESULTS}

There were 426 patients with stage I endometrial cancer at Songklanagarind Hospital. Of these, 25 patients who had carcinosarcoma, 23 patients who had two primary cancers and 110 patients who had a follow-up time of less than 2 years were excluded. Finally, 268 patients were enrolled into the study.
The demographic and histologic data in NAT group, AT group and all patients are shown in Table 1. The median age at the time of diagnosis was 55 years (range of 2582 years). The median follow-up time was 60.3 months (range of 8.7-173.9 months). Two-third of the patients was multipara and had a BMI of more than $23 \mathrm{~kg} / \mathrm{m}^{2}$. One-third of the patients had hypertension and $20 \%$ had DM and dyslipidemia. The median of interval between diagnosis and surgery was 7.9 weeks (range of 0.1-158 weeks), and $63.4 \%$ of the patients underwent complete surgical staging. Two-third and half of the patients had grade 1 endometrioid type and tumor size of more than $2 \mathrm{~cm}$, respectively.

Table 1. Baseline characteristics of all patients with stage I endometrial cancer



Note: NAT; non-adjuvant therapy, AT; adjuvant therapy, BMI; body mass index, BSO; bilateral salpingooophorectomy, PLD; pelvic lymph node dissection, PPLD; pelvic and para-aortic lymph node dissection, DOD; dead without disease, DWD; dead with disease, AOD; alive without disease, AWD; alive with disease 
The median ratio of MI was 0.26 . The presence of LVSI was noted in 34 patients $(12.7 \%)$. However, there were missing data in $39.9 \%$. One hundred and eleven patients $(41.4 \%)$ received AT by external beam radiotherapy (EBRT), vaginal brachytherapy (VB), EBRT \& VB, chemotherapy (CMT) and CMT\&VB in $13.8 \%, 8.6 \%, 17.2 \% 0.7 \%$ and $1.1 \%$, respectively. The difference demographic factors between NAT and AT group were median age (53 versus 58 years), nonendometrioid type, grade 3 , tumor size $>2 \mathrm{~cm}$, median of ratio of MI (o.1 versus 0.5), and FIGO stage IB $(\mathrm{p}<0.05)$.

The median follow-up times in patients with and without recurrence of disease were 42.1 months (range of 8.7-112.5 months) and 60.0 months (range of 24.1171.1 months), respectively. The recurrent of disease was found in 22 patients $(8.2 \%), 7$ patients $(4.5 \%)$ and 15 patients $(13.5 \%)$ in all patients, NAT group and AT group, respectively. Half of the patients had distant metastasis. The 2- and 5-year DFS were 94.4\% and 91.6\%, respectively (Fig. 1). The 5-year DFS in NAT group was significantly longer than AT group $(95.2 \%$ versus $86.5 \%$ ) (Fig. 2). Twenty one patients died (7.8\%), 11 patients died with disease, whereas 10 patients died without disease. Among NAT and AT groups, there were recurrent/dead patients in 7/5 and $15 / 16$, respectively. There was no difference of DFS and overall survival between both groups.

Table 2. Factors associated with recurrence in non-adjuvant treatment, adjuvant treatment and all patients.

\begin{tabular}{|c|c|c|c|c|c|c|c|c|c|}
\hline \multirow{3}{*}{ Features } & \multicolumn{3}{|c|}{$\begin{array}{c}\text { NAT } \\
(\mathrm{N}=157), \mathrm{n}(\%)\end{array}$} & \multicolumn{3}{|c|}{$\begin{array}{c}\mathrm{AT} \\
(\mathrm{N}=111), \mathrm{n}(\%)\end{array}$} & \multicolumn{3}{|c|}{$\begin{array}{c}\text { Total } \\
(\mathrm{N}=268), \mathrm{n}(\%)\end{array}$} \\
\hline & $\begin{array}{l}\text { Non- } \\
\text { recurrence }\end{array}$ & Recurrence & $\begin{array}{c}\mathrm{P} \\
\text { value }\end{array}$ & $\begin{array}{l}\text { Non- } \\
\text { recurrence }\end{array}$ & Recurrence & $\begin{array}{c}\mathrm{P} \\
\text { value }\end{array}$ & $\begin{array}{c}\text { Non- } \\
\text { recurrence }\end{array}$ & Recurrence & $\begin{array}{c}\mathrm{P} \\
\text { value }\end{array}$ \\
\hline & $(n=150)$ & $(n=7)$ & & $(n=96)$ & $(n=15)$ & & $(\mathrm{n}=246)$ & $(n=22)$ & \\
\hline Age (Median, IQR) & $\begin{array}{c}52.5 \\
(47,59)\end{array}$ & $\begin{array}{c}59 \\
(55.5,65)\end{array}$ & 0.02 & $\begin{array}{c}56.1 \\
(48.4,63.8)\end{array}$ & $\begin{array}{c}60.5(52.6 \\
68.4)\end{array}$ & 0.04 & $\begin{array}{c}55 \\
(48.2,60)\end{array}$ & $59.5(57,62)$ & $<0.01$ \\
\hline $\begin{array}{l}\text { Parity } \\
\text { Nullipara } \\
\text { Multipara }\end{array}$ & $\begin{array}{l}45(31.9) \\
96(68.1)\end{array}$ & $\begin{array}{l}1(14.3) \\
6(85.7)\end{array}$ & 0.44 & $\begin{array}{l}25(27.5) \\
66(72.5)\end{array}$ & $\begin{array}{c}2(13.3) \\
13(86.7)\end{array}$ & 0.35 & $\begin{array}{c}70(30.2) \\
162(69.8)\end{array}$ & $\begin{array}{c}3(13.6) \\
19(86.4)\end{array}$ & 0.16 \\
\hline $\begin{array}{l}\text { BMI }\left(\mathrm{kg} / \mathrm{m}^{2}\right) \\
\quad<23 \\
\geq 23\end{array}$ & $\begin{array}{c}33(23.1) \\
110(76.9)\end{array}$ & $\begin{array}{l}4(57.1) \\
3(42.9)\end{array}$ & 0.06 & $\begin{array}{l}21(22.8) \\
71(77.2)\end{array}$ & $\begin{array}{l}7(46.7) \\
8(53.3)\end{array}$ & 0.06 & $\begin{array}{c}54(23) \\
181(77)\end{array}$ & $\begin{array}{l}11(50) \\
11(50)\end{array}$ & 0.01 \\
\hline $\begin{array}{l}\text { DM } \\
\text { HT } \\
\text { DLP } \\
\text { Time from } \\
\text { Diagnosis to } \\
\text { Surgery (Mean, } \\
\text { IQR) }\end{array}$ & $\begin{array}{c}30(20) \\
49(32.7) \\
28(18.7) \\
8(5.3 \\
10.9)\end{array}$ & $\begin{array}{c}1(14.3) \\
5(71.4) \\
0(0) \\
9.1(7.5, \\
11.1)\end{array}$ & $\begin{array}{l}1.00 \\
0.05 \\
0.35 \\
0.38\end{array}$ & $\begin{array}{c}20(20.8) \\
34(35.4) \\
15(15.6) \\
7.9(6, \\
11.6)\end{array}$ & $\begin{array}{c}1(6.7) \\
5(33.3) \\
2(13.3) \\
5.5(4.4, \\
8.4)\end{array}$ & $\begin{array}{l}0.30 \\
1.00 \\
1.00 \\
0.10\end{array}$ & $\begin{array}{c}50(20.3) \\
83(33.7) \\
43(17.5) \\
8(5.6 \\
11.1)\end{array}$ & $\begin{array}{c}2(9.1) \\
10(45.5) \\
2(9.1) \\
7(4.9,9.1)\end{array}$ & $\begin{array}{l}0.27 \\
0.38 \\
0.55 \\
0.44\end{array}$ \\
\hline $\begin{array}{l}\text { Operative procedure } \\
\text { Hysterectomy+ } \\
\text { BSO }\end{array}$ & $33(22)$ & $1(14.3)$ & 0.233 & $16(16.7)$ & $2(13.3)$ & 0.18 & 49 (19.9) & $3(13.6)$ & 0.09 \\
\hline $\begin{array}{l}\text { Hysterectomy+ } \\
\text { BSO+PLD }\end{array}$ & $26(17.3)$ & $1(14.3)$ & & $14(14.5)$ & $5(33.4)$ & & $40(16.3)$ & $6(27.3)$ & \\
\hline $\begin{array}{l}\text { Hysterectomy+ } \\
\text { BSO+PPLD }\end{array}$ & $91(60.7)$ & $5(71.4)$ & & $66(68.8)$ & $8(53.3)$ & & $157(63.8)$ & $13(59.1)$ & \\
\hline $\begin{array}{l}\text { Histologic type } \\
\text { Non-endometrioid } \\
\text { Endometrioid }\end{array}$ & $\begin{array}{c}6(4) \\
144(96)\end{array}$ & $\begin{array}{c}0(0) \\
7(100)\end{array}$ & 1.00 & $\begin{array}{l}13(13.5) \\
83(86.5)\end{array}$ & $\begin{array}{c}2(13.3) \\
13(86.7)\end{array}$ & 1.00 & $\begin{array}{c}19(7.7) \\
227(92.3)\end{array}$ & $\begin{array}{c}2(9.1) \\
20(90.9)\end{array}$ & 0.69 \\
\hline $\begin{array}{l}\text { Tumor grading } \\
\text { Grade } 1 \\
\text { Grade } 2 \\
\text { Grade } 3\end{array}$ & $\begin{array}{c}114(76) \\
33(22) \\
3(2)\end{array}$ & $\begin{array}{l}3(42.9) \\
2(28.6) \\
2(28.6)\end{array}$ & 0.01 & $\begin{array}{l}39(40.6) \\
30(31.2) \\
27(28.1)\end{array}$ & $\begin{array}{l}3(20) \\
6(40) \\
6(40)\end{array}$ & 0.30 & $\begin{array}{l}153(62.2) \\
63(25.6) \\
30(12.2)\end{array}$ & $\begin{array}{l}6(27.3) \\
8(36.4) \\
8(36.4)\end{array}$ & $<0.01$ \\
\hline $\begin{array}{l}\text { Tumor size }(\mathrm{cm}) \\
\leq 2 \\
>2\end{array}$ & $\begin{array}{l}63(47.4) \\
70(52.6) \\
\end{array}$ & $\begin{array}{c}0(0) \\
7(100)\end{array}$ & 0.01 & $\begin{array}{l}15(20) \\
60(80)\end{array}$ & $\begin{array}{c}0(0) \\
11(100)\end{array}$ & 0.20 & $\begin{array}{c}78(37.5) \\
130(62.5) \\
\end{array}$ & $\begin{array}{c}0(0) \\
18(100)\end{array}$ & $<0.01$ \\
\hline $\begin{array}{l}\text { Ratio of MI, } \\
\text { Median (IQR) }\end{array}$ & $0.1(0,0.3)$ & $\begin{array}{c}0.3(0.2 \\
0.4)\end{array}$ & 0.05 & $0.5(0.3)$ & $0.7(0.1)$ & 0.01 & $0.2(0,0.4)$ & $0.7(0.4,0.8)$ & $<0.01$ \\
\hline Presence of LVSI & $3(2)$ & $3(42.9)$ & $<0.01$ & $22(22.9)$ & $6(40)$ & 0.35 & $25(10.2)$ & $9(40.9)$ & $<0.01$ \\
\hline
\end{tabular}


The median age at diagnosis, BMI, tumor grading, tumor size, ratio of MI, and presence of LVSI were the potential risk factors for recurrent of cancer. In NAT group, the potential risk factors associated with recurrence were the same as in all patients, with the exception of; BMI $(p=0.06)$ and the ratio of MI, which were not statistically significant $(\mathrm{p}=0.05)$. While in AT group, only the age $(\mathrm{p}=0.04)$ and ratio of MI were statistically significant $(\mathrm{p}=0.01)$ (Table 2$)$. The multivariate analysis was not calculated because there were a lot of missing data.

\section{DISCUSSION}

The present study showed that the recurrence rate of stage I endometrial cancer was $8.2 \%$. The RR was lower than those in other studies (11.2-19.0\%) (Creutzberg et al 2000, Demiral et al 2014, Gadducci et al 2014, Keys et al 2004), which also included patients with stage II endometrial cancer, but excluded patients without MI. However, the RR in the present study was worse than other previous studies (4.8-7.0\%) (Huijgens et al 2013, Jeppesen et al 2016, Rahatli et al 2014, Therasakvichya et al 2016, Zaki et al 2012) because of the large number of participants (Jeppesen et al 2016) that included only patients without MI (Zaki et al 2012).

In this present study, the 2- and 5-DFS rates were $94.4 \%$ and $91.6 \%$, respectively. The 5-year DFS was less than that in the previous studies of 93-94.4\% (Rahatli et al 2014, Therasakvichya et al 2016, Zaki et al 2012). The DFS in NAT group was significantly better than that in AT group $(95.2 \%$ versus $86.5 \%)$. It was possibly because the patients, who were selected for AT, had a high risk for recurrence. These results were different from the previous study that showed a lower rate of 5year DFS in the NAT group than that in the AT group (69.3\% versus $75.3 \%, \mathrm{p}=0.24)$ (Gadducci et al 2014).

The potential risk factors associated with recurrence in all patients were median age at diagnosis, BMI, tumor grading, tumor size, ratio of MI, presence of LVSI, and lower uterine involvement. With the median age at diagnosis, the significant value was 59.5 years, when compared to the previous studies, old age also was a significant factor associated with recurrence, but they used a different cut point (range, 60-70 years) (Creutzberg et al 2000, Jeppesen et al 2016, Therasakvichya et al 2016) also with tumor grading there was an association with the recurrence, the same as in the previous studies (Creutzberg et al 2000, Creutzberg et al 2004, Keys et al 2004, Zaki et al 2012). In the PORTEC-1 study, tumor grading was combined with age and MI for predicting the recurrence (Creutzberg et al 2000), with this combination, and additionally with the presence of LVSI, these were associated with recurrence in the GOG-99 study (Keys et al 2004). The presence of LVSI was a potential factor associated with recurrence in the previous studies too (Creutzberg et al 2004, dos Reis et al 2015). BMI was associated with the recurrence and there was no previous study to our knowledge of this factor. Nonendometrioid type was not significant factor associated with recurrence of disease, which was differed from the previous study (Jeppesen et al 2016). This might be because of the large number of patients, and ratio of non-endometrioid type being more than the present study.

In NAT group, the RR was $4.4 \%$, and the 5-year DFS was $95.2 \%$. The RR was lower than that in the previous studies that included stage II patients (Keys et al 2004), but higher than that in the study by Lajer, which included only patients with stage I endometrial cancer without MI (Lajer et al 2012). In this group, the potential factors associated with recurrence were the same in all patients, with the exception of BMI and ratio of MI, which no previous study, has reported. In AT group, the RR was $13.5 \%$, which was higher than those in the previous studies, in a range of 6.8-7.2\% (Dunn et al 2014, Keys et al 2004, Kim et al 2016. Rahatli et al 2014), and the 5-year DFS was $86.5 \%$, which was less than those in the previous studies (92.5-98.4\%) (Dunn et al 2014, Kim et al 2016). Age was associated with recurrence as same as in the previous study (Dunn et al 2014), but stage IB, grade 3, non-endometrioid type along with patients who underwent lymphadenectomy were not correlated with recurrence of disease. The ratio of MI was a significant factor associated with recurrence and there was no study to compare this too.

The strengths of the present study were that all patients were treated, and followed up at a single center in southern Thailand. However, there were inadequate data in some baseline characteristics because this was a retrospective study and the pathological factors were not reviewed. Also, this study had many patients who were lost to follow-up. For clinical application, all potential risk factors associated with recurrence may be used in the consideration of AT because of a trend in recurrent disease, and to provide a proper follow-up.

\section{CONCLUSION}

Recurrence disease still occurred in stage I endometrial cancer, even though it had a good prognosis. DFS in the NAT group was longer than in the AT group. Potential factors associated with recurrence were tumor grade, tumor size more than $2 \mathrm{~cm}$, more than half $\mathrm{MI}$, and presence of LVSI. 


\section{ACKNOWLEDGMENT}

This study was supported by the Faculty of Medicine, Prince of Songkhla University. We would like to give our sincere thanks to Ms. Nannapat Pruphetkaew for helping in statistical analysis and Mr. Glenn Shingledecker for English writing correction.

\section{REFERENCES}

Colombo N, Creutzberg C, Amant F, et al (2016). ESMO-ESGO-ESTRO Consensus Conference on Endometrial Cancer: Diagnosis, Treatment and Follow-up. Int J Gynecol Cancer 26, 2-30

Creutzberg CL, van Putten WL, Koper PC, et al (2000). Surgery and postoperative radiotherapy versus surgery alone for patients with stage- 1 endometrial carcinoma: multicentre randomised trial. PORTEC Study Group. Post Operative Radiation Therapy in Endometrial Carcinoma. Lancet 355, 1404-1411

Creutzberg C L, van Putten WL, Warlam-Rodenhuis $\mathrm{CC}$, et al (2004). Outcome of high-risk stage IC, grade 3 , compared with stage I endometrial carcinoma patients: the Postoperative Radiation Therapy in Endometrial Carcinoma Trial. J Clin Oncol 22, 12341241

Demiral S, Beyzadeoglu M, Sager O, et al (2014). Evaluation of treatment outcomes of early-stage endometrial cancer radiotherapy: a single center experience. Asian Pac J Cancer Prev 15, 9599-9602

dos Reis R, Burzawa JK, Tsunoda AT, et al (2015). Lymphovascular Space Invasion Portends Poor Prognosis in Low-Risk Endometrial Cancer. Int J Gynecol Cancer 25, 1292-1299

Dunn EF, Geye H, Platta CS, et al (2014). Predictive factors of recurrence following adjuvant vaginal cuff brachytherapy alone for stage I endometrial cancer. Gynecol Oncol 133, 494-498

Gadducci A, Cosio S, Landoni F, et al (2014). Adjuvant treatment and analysis of failures in patients with high-risk FIGO Stage Ib-II endometrial cancer: an Italian multicenter retrospective study (CTF study). Gynecol Oncol 134, 29-35

Hacker NF, Friedlander ML (2015). Uterine Cancer. In Berek JS, Hacker NF (eds.), Berek \& Hacker's Gynecologic Oncology (6th ed.), China, Wolters Kluwer, p 390-442

Haltia UM, Butzow R, Leminen A, et al (2014). FIGO 1988 versus 2009 staging for endometrial carcinoma: a comparative study on prediction of survival and stage distribution according to histologic subtype. $\mathrm{J}$ Gynecol Oncol 25, 30-35
Huijgens AN, Mertens HJ (2013). Factors predicting recurrent endometrial cancer. Facts Views Vis Obgyn 5, 179-186

Imsamran W, Chaiwerawattana A, Wiangnon S, et al (2015). Cancer in Thailand Vol.VIII, 2010-2012. Bangkok: New Thammada Press.

Jeppesen MM, Jensen PT, Hansen G, et al (2016). The nature of early-stage endometrial cancer recurrence-A national cohort study. Eur J Cancer 69, 51-60

Keys HM, Roberts JA, Brunetto VL, et al (2004). A phase III trial of surgery with or without adjunctive external pelvic radiation therapy in intermediate risk endometrial adenocarcinoma: a Gynecologic Oncology Group study. Gynecol Oncol 92, 744-751

Kim J, Lee KJ, Park KR, et al (2016). Treatment outcomes after adjuvant radiotherapy following surgery for patients with stage I endometrial cancer. Radiat Oncol J 34, 265-272

Koskas M, Huchon C, Amant F (2016). Characteristics and prognosis of patients with early-stage endometrial cancer who refuse adjuvant radiotherapy. Gynecol Oncol 141, 428-433

Lajer H, Elnegaard S, Christensen RD, et al (2012). Survival after stage IA endometrial cancer; can follow-up be altered? A prospective nationwide Danish survey. Acta Obstet Gynecol Scand 91, 976982

NCCN.org (2018). Pennsylvania.: National Comprehensive Cancer Network. (2018). NCCN Clinical Practice Guideline in Oncology (NCCN Guidelines) : Uterine Neoplasms. [updated 2018 October 17]. Available from http://www.nccn.org/. Accessed November 6, 2018

Rahatli S, Dizdar O, Kucukoztas N, et al (2014). Good outcomes of patients with stage IB endometrial cancer with surgery alone. Asian Pac J Cancer Prev 15, 38913893

Therasakvichya S, Kuljarusnont S, Petsuksiri J, et al (2016). Clinical outcomes of stage I endometrial carcinoma patients treated with surgery alone: Siriraj Hospital experiences. J Gynecol Oncol 27, e48

WCRF.org (2018). London: Wolrd Cancer Research Fund, \& American Institute for Cancer Research. Endometrial cancer statistics. Available from https://www.wcrf.org/dietandcancer/cancertrends/endometrial-cancer-statistics. Accessed November 6, 2018

Zaki MA, Robbins JR, Fatteh S, et al (2012). Histological grade predicts for recurrence in patients with uterine endometrioid carcinoma without myometrial involvement. Anticancer Res 32, 40614065 